\title{
Kilka uwag o stanie badań nad kompetencją słowotwórczą dzieci z niepełnosprawnością intelektualną
}

\begin{abstract}
Renata Marciniak-Firadza, Kilka uwag o stanie badań nad kompetencja stowotwórcza dzieci z niepetnosprawnościa intelektualna [A few remarks on the status of research on the word-formative competence in children with intellectual disability]. Interdyscyplinarne Konteksty Pedagogiki Specjalnej, nr 18, Poznań 2017. Pp. 145-163. Adam Mickiewicz University Press. ISSN 2300-391X

Description of understanding and creating word-formative structures by children with slight intellectual disability and specifying how these word-formative structures exist in the linguistic awareness of such children is important, as there has been no research and therefore no studies related to the word-formation competence in children with intellectual disability. The only data related to the wordformation competence in children with intellectual disability we have are the names of professions collected by A. Wątorek in her research on the linguistic competence responsible for the development of lexical skills. The data incorporated in the said study allowed to perform linguistic, word-formative analysis and hence made it possible to indicate the methods of coding the names of professions/persons performing certain activities by children with slight intellectual disability.
\end{abstract}

KEY WORDS: intellectual disability, language competence, word-forming competence 
W rozwoju językowym i poznawczym dziecka istotną rolę, jak podkreśla Ewa Muzyka-Furtak11, odgrywa słowotwórstwo. Pomiędzy znajomością reguł słowotwórczych a stopniem opanowania kompetencji językowej zachodzi bowiem ścisła korelacja: „kształcenie umiejętności interpretacji formacji słowotwórczych, a następnie możliwości aktywnego wykorzystania znajomości reguł tworzenia derywatów, to najważniejsze przejawy kształtowania kompetencji językowej na poziomie leksykalnym"2.

O tym, że rola słowotwórstwa jest marginalizowana i niedoceniana przez badaczy, szczególnie w odniesieniu do dzieci niepełnosprawnych intelektualnie, świadczą dwa fakty. Po pierwsze, o ile istnieją $w$ języku polskim opracowania poświęcone ( $w$ całości lub częściowo) kształtowaniu się podstaw słowotwórczych w systemie językowym dziecka w normie intelektualnej (por. np. prace: Marii Zarębiny $^{3}$, Leona Kaczmarka ${ }^{4}$, Marii Chmury-Klekotowej ${ }^{5}$, Stefana Szumana ${ }^{6}$, Jana Baudouin de Curtenay' ${ }^{7}{ }^{7}$, Heleny Synowiec ${ }^{8}$, Stani-

${ }^{1}$ E. Muzyka-Furtak, Kwestionariusz słowotwórczy w ocenie kompetencji językowej dzieci z zaburzeniem stuchu, [w:] Metody $i$ narzędzia diagnostyczne w logopedii, red. M. Kurowska, E. Wolańska, Dom Wydawniczy Elipsa, Warszawa 2015, s. 251.

${ }^{2}$ M. Pastuchowa, O stowotwórstwie z perspektywy leksykalnej, [w:] Sztuka czy rzemiosto? Nauczyć Polski i polskiego, red. A. Achtelik, J. Tambor, Wydawnictwo Gnome, Katowice 2007, s. 23.

${ }^{3}$ M. Zarębina, Kształtowanie się systemu językowego dziecka, Wydawnictwo Ossolineum, Wrocław 1965; M. Zarębina, Język polski w rozwoju jednostki. Analiza tekstów dzieci do wieku szkolnego. Rozwój semantyczny języka dziecka, Wydawnictwo Naukowe Wyższej Szkoły Pedagogicznej, Kraków 1980.

${ }^{4}$ L. Kaczmarek, Nasze dziecko uczy się mowy, Wydawnictwo Lubelskie, Lublin 1966.

${ }^{5} \mathrm{M}$. Chmura-Klekotowa, Neologizmy słowotwórcze w mowie dzieci (I), „Poradnik Językowy" 1967, nr 10, s. 433-445; M. Chmura-Klekotowa, Neologizmy stowotwórcze w mowie dzieci, "Poradnik Językowy” 1968, nr 1, s. 19-25; M. Chmura-Klekotowa, Neologizmy stowotwórcze w mowie dzieci, „Prace Filologiczne”1971, nr 21, s. 99-235.

${ }^{6}$ S. Szuman, Rozwój treści słownika dzieci. Zagadnienia i niektóre wyniki badań, [w:] O rozwoju języka i myślenia dziecka, red. S. Szuman, Wydawnictwo PWN, Warszawa 1968, s. 19-95.

${ }^{7}$ J. Baudouin de Courtenay, Spostrzeżenia nad językiem dziecka, wybór i opracowanie M. Chmura-Klekotowa, Wydawnictwo Ossolineum, Wrocław 1974.

${ }^{8} \mathrm{H}$. Synowiec, Z badań nad stownictwem dzieci przedszkolnych, [w:] Z teorii i praktyki dydaktycznej języka polskiego, t. 3, red. J. Kram, E. Polański, Wydawnictwo Uni- 
sława Grabiasa ${ }^{9}$, Krystyny Gąsiorek ${ }^{10}$, Alicji Rakowskiej11, Kazimiery Krakowiak12, Marii Przybysz-Piwkowej13, Łucji Dawid14, Ewy Haman15, Małgorzaty Mnich16, Ewy Muzyki-Furtak17, Amelii Dziur-

wersytetu Śląskiego, Katowice 1980; H. Synowiec, Rozwój słownictwa nazywającego rozwój osobowości w języku dzieci i młodzieży, Wydawnictwo Uniwersytetu Śląskiego, Katowice 1985.

${ }^{9}$ S. Grabias, O ekspresywności języka. Ekspresja a słowotwórstwo, Wydawnictwo Lubelskie, Lublin 1981.

${ }^{10}$ K. Gąsiorek, Rozumienie przez dzieci i młodzież szkolna rzeczowników abstrakcyjnych z uwzględnieniem czynników wiekowych i środowiskowych, [w:] Zagadnienia komunikacji jezykowej dzieci i młodzieży, red. J. Porayski-Pomsta, Dom Wydawniczy „Elipsa", Warszawa 1991.

11 A. Rakowska, Rozwój systemu gramatycznego u dzieci głuchych, Wydawnictwo Naukowe Wyższej Szkoły Pedagogicznej, Kraków 1992.

12 K. Krakowiak, Fonogesty jako narzędzie formowania języka u dzieci z uszkodzonym stuchem, seria: Komunikacja jezykowa i jej zaburzenia, t. 9, red. S. Grabias, Wydawnictwo Uniwersytetu Marii Curie-Skłodowskiej, Lublin 1995.

${ }^{13}$ M. Przybysz-Piwkowa, Wyodrębnianie znaczeń form językowych w neologizmach dziecięcych, [w:] Językowy obraz świata dzieci i młodzieży, red. J. Ożdżyński, Wydawnictwo Wyższej Szkoły Pedagogicznej, Kraków 1995.

${ }^{14}$ Ł. Dawid, Neologizmy przykładem kreatywności językowej uczniów klas młodszych, [w:] Problemy edukacji lingwistycznej, pod red. M.T. Michalewskiej, Oficyna Wydawnicza „Impuls”, Katowice 1999.

${ }^{15}$ E. Haman, Status wyrazów pochodnych w stowniku dziecka - analiza psycholingwistyczna (niepublikowana rozprawa doktorska napisana pod kierunkiem prof. dr hab. Barbary Bokus, Wydział Psychologii UW) 2000; E. Haman, Semantic vs. formal determinants of derivational morphology development: The case of derived nouns in Polish, „Polish Psychological Bulletin” 2000, nr 31(2), s. 123-136; E. Haman, Early productivity in derivation. A case study of diminutives in the acquisition of Polish, "Psychology of Language and Communication" 2003, nr 7(1), s. 37-56; E. Haman, Stowotwórstwo dziecięce w badaniach psycholingwistycznych, Wydawnictwo Lexem, Warszawa 2013.

${ }^{16}$ M. Mnich, Sprawność językowa dzieci w wieku wczesnoszkolnym, Oficyna Wydawnicza „Impuls”, Kraków 2002.

17 E. Muzyka, Sposoby interpretowania konstrukcji stowotwórczych przez dzieci niestyszace, "Logopedia” 2007, nr 36, s. 95-115; E. Muzyka, Acquisition of word-formation categories by children with hearing loss, „Psychology of Language and Communication" 2008, nr 12(2), s. 45-68; E. Muzyka-Furtak, Gtuchota i niedostuch - mechanizmy nabywania wyrazów pochodnych, "Logopedia” 2009, nr 38, s. 149-172; E. Muzyka-Furtak, Konstrukcje stowotwórcze w świadomości językowej dzieci niestyszących, Wydawnictwo Uniwersytetu Marii Curie-Skłodowskiej, Lublin 2010; E. Muzyka-Furtak, Kon- 
dy-Multan ${ }^{18}$, Alicji Giermakowskiej19), o tyle publikacji poświęconych słowotwórstwu dzieci $\mathrm{z}$ niepełnosprawnością intelektualną nie ma. Po drugie, chociaż mowa i język dzieci z niepełnosprawnością intelektualną były przedmiotem naukowych opisów i opracowań (por. np. wady wymowy u osób upośledzonych umysłowo badane były przez Annę Szuniewicz ${ }^{20}$ i Elżbietę Minczakiewicz ${ }^{21}$. Badania umiejętności mówienia i pisania w szkołach dla dzieci z lekkim stopniem upośledzenia umysłowego prowadziła Sławomira Sadowska ${ }^{22}$. Słownictwo badała Lucyna Błeszyńska23, występują-

strukcje słowotwórcze a kategorie poznawcze dzieci niestyszących, [w:] Język a kultura, t. 22, Idiolekty w różnych sferach komunikacji, red. A. Żurek, Wydawnictwo Uniwersytetu Wrocławskiego, Wrocław 2011, s. 117-132; E. Muzyka-Furtak, Jakościowa charakterystyka zaburzeń leksykalnych dzieci z uszkodzonym stuchem, "Logopedia” 2013, nr 42, s. 135-150; E. Muzyka-Furtak, Kwestionariusz słowotwórczy w ocenie..., s. 251-267.

18 A. Dziurda-Multan, Dziecięce sposoby tworzenia nazw, Wydawnictwo KUL, Lublin 2008.

19 A. Giermakowska, Ocena kompetencji stowotwórczej uczniów z trudnościami w czytaniu i pisaniu na poziomie edukacji wczesnoszkolnej, „Szkoła Specjalna” 2012, nr 5, s. 356-366.

${ }^{20}$ A. Szuniewicz Próba badania wad mowy dzieci upośledzonych umystowo w warszawskich szkołach specjalnych, "Logopedia” 1967, nr 7, s. 112-117.

${ }^{21}$ E. Minczakiewicz, Z badań nad zaburzeniami mowy u dzieci upośledzonych umysłowo, [w:] Z zagadnień oligofrenopedagogiki, t. 2, red. J. Pańczyk, Wydawnictwo WSPS, Warszawa 1989; E. Minczakiewicz, Zaburzenia mowy i ich odbicie w piśmie uczniów młodszych klas szkoły specjalnej dla lekko upośledzonych umystowo, "Logopedia” 1993, nr 20, s. 113-119; E. Minczakiewicz, Zaburzenia mowy u osób z upośledzeniem umystowym, "Scholasticus” 1993, nr 1, s. 57-63; E. Minczakiewicz, Rozwój języka mówionego uczniów młodszych klas szkoły specjalnej dla lekko upośledzonych umystowo w toku zamierzonych oddziatywań stymulacyjnych, "Logopedia” 1994, nr 21, s. 37-46.

22 S. Sadowska, Uczeń z niepetnosprawnościa intelektualna w stopniu lekkim w szkolnej sytuacji komunikacyjnej. O realizacji zadań wspomagania rozwoju umiejętności mówienia i pisania, [w:] Nauczanie uczniów z niepetnosprawnościa intelektualna w stopniu lekkim. Wybrane problemy z teorii i praktyki, red. S. Sadowska, Wydawnictwo Edukacyjne Akapit, Toruń 2006, s. 127-151.

${ }^{23}$ L. Błeszyńska, Zasób słownictwa uczniów z niepetnosprawnościq intelektualna w stopniu lekkim klas gimnazjalnych - diagnoza i propozycje rozwiąań, [w:] Nauczanie uczniów z niepetnosprawnością intelektualna w stopniu lekkim. Wybrane problemy z teorii i praktyki, red. S. Sadowska, Wydawnictwo Edukacyjne Akapit, Toruń 2006, s. 153-162. 
ce $\mathrm{w}$ mowie agramatyzmy Zbigniew Tarkowski²4, a kompetencje narracyjne Hanna Nadolska ${ }^{25}$. Sprawności językowe dzieci upośledzonych umysłowo $\mathrm{w}$ stopniu lekkim zostały omówione $\mathrm{w}$ pracy pod redakcją Józefy Bałachowicz i Jana Paluszewskiego'26, a umiejętności językowe i komunikacyjne w monografii Alicji Rakowskiej27. W badaniach nad rozwojem mowy u osób z niepełnosprawnością intelektualną na szczególną uwagę zasługują prace Elżbiety Minczakiewicz ${ }^{28}$. Językowy obraz emocji w wypowiedziach dzieci upośledzonych umysłowo opracowała Urszula Jęczeń ${ }^{29}$. Kompetencje lingwistyczne uczniów szkoły specjalnej na podstawie tworzonych przez nich eksplikacji znaczeń nazw żywiołów przedstawił Mirosław Michalik ${ }^{30}$. Ten sam autor dokonał oceny stopnia przyswojenia umiejętności syntaktycznych przez osoby z oligofazją oraz

24 Z. Tarkowski, Agramatyzm u uczniów lekko upośledzonych umysłowo, [w:] Rewalidacja dzieci ze złożonymi upośledzeniami, red. Z. Sękowska, Wydawnictwo UMCS, Lublin 1988, s. 81-108.

${ }^{25}$ H. Nadolska, Poziom inteligencji a sprawność relacjonowania zdarzeń. Wybrane aspekty badań nad kompetencja narracyjna dzieci petnosprawnych i upośledzonych umystowo w stopniu lekkim, „Kultura i Edukacja” 1993, nr 4, s. 91-102; H. Nadolska, Poziom inteligencji a sprawność narracji. (Z badań nad mowa narracyjna dzieci upośledzonych umystowo w stopniu lekkim i petnosprawnych umystowo), "Roczniki Pedagogiki Specjalnej” 1994, nr 5, s. 43-61; H. Nadolska, Kompetencja narracyjna uczniów o różnym poziomie intelektualnym. Przejawy, uwarunkowania, tendencje rozwojowe, Wydawnictwo Erbe, Białystok 1995.

${ }^{26}$ Sprawności językowe dzieci upośledzonych umysłowo w stopniu lekkim, red. J. Bałachowicz, J. Paluszewski, Wydawnictwo WSPS, Warszawa 1995.

27 A. Rakowska, Język - komunikacja - niepetnosprawność. Wybrane zagadnienia, Wydawnictwo Naukowe Akademii Pedagogicznej, Kraków 2003.

28 E. Minczakiewicz, Kształtowanie i usprawnianie mowy dzieci upośledzonych umysłowo w stopniu umiarkowanym i znacznym, „Szkoła Specjalna” 1984, nr 3, s. 186-191.

${ }^{29}$ U. Jęczeń, Językowa projekcja emocji na przykładzie wypowiedzi dzieci upośledzonych umystowo i dzieci w normie intelektualnej (niepublikowana rozprawa doktorska), Lublin 2005; U. Jęczeń, Językowa projekcja emocji. Emocje w zachowaniach językowych dzieci upośledzonych umysłowo i dzieci w normie intelektualnej, [w:] Język - interakcja zaburzenia mowy. Metodologia badań, red. T. Woźniak, A. Domagała, Wydawnictwo UMCS, Lublin 2007, s. 133-171.

${ }^{30}$ M. Michalik, Diagnozowanie kompetencji lingwistycznej ucznia szkoty specjalnej, Wydawnictwo Naukowe Akademii Pedagogicznej, Kraków 2006. 
z mózgowym porażeniem dziecięcym na tle rozwijających się zdolności składniowych dzieci w wieku od czterech do dziesięciu lat ${ }^{31}$. Wyrażeniom przyimkowym w mowie dzieci upośledzonych w stopniu umiarkowanym i lekkim poświęcona jest nieopublikowana rozprawa doktorska Katarzyny Kaczorowskiej-Bray ${ }^{32}$. Z nowszych prac należy wymienić monografie: Doroty Krzemińskiej ${ }^{33}$ podejmującą zagadnienia języka i dyskursu codziennego osób z niepełnosprawnością intelektualną, Jacka Błeszyńskiego ${ }^{34}$ poświęconą zagadnieniom mowy, języka i komunikacji u osób z niepełnosprawnością intelektualną oraz Agnieszki Wątorek ${ }^{35}$, w której autorka postawiła sobie za cel przygotowanie na podstawie materiału empirycznego możliwie wyczerpującej charakterystyki umiejętności leksykalnych, gramatycznych i narracyjnych dzieci z lekką niepełnosprawnością intelektualną tak w aspekcie rozumienia - recepcji, jak również produkcji mowy - ekspresji), to jednak nikt z badaczy nie podjął próby opisu kompetencji słowotwórczych dzieci z lekką niepełnosprawnością intelektualną.

Rozprawą naukową, na podstawie której można wysnuć wnioski dotyczące wybranych aspektów kompetencji słowotwórczych dzieci z dysfunkcją intelektualną, jest przytaczana wyżej praca Agnieszki Wątorek, pedagoga specjalnego, logopedy i neurologopedy pt. Kompetencja językowa uczniów z lekka niepetnosprawnościa intelektualna. Co prawda autorka nie badała kompetencji słowotwórczych dzieci z niepełnosprawnością intelektualną, a jedynie kompetencję językową odpowiedzialną za przyrost umiejętności

${ }^{31}$ M. Michalik, Kompetencja składniowa w normie i w zaburzeniach, Wydawnictwo Naukowe Uniwersytetu Pedagogicznego, Kraków 2011.

32 K. Kaczorowska-Bray, Wyrażenia przyimkowe w mowie dzieci upośledzonych umystowo w stopniu umiarkowanym i lekkim (niepublikowana rozprawa doktorska), Gdańsk 2007.

${ }^{33}$ D. Krzemińska, Język i dyskurs codzienny osób z niepetnosprawnością intelektualną, Oficyna Wydawnicza „Impuls”, Kraków 2012.

34 J. Błeszyński, Niepetnosprawność intelektualna. Mowa - język - komunikacja. Czy iloraz inteligencji wyjaśnia wszystko?, Harmonia, Gdańsk 2013.

35 A. Wątorek, Kompetencja językowa uczniów z lekką niepetnosprawnością intelektualna, Wydawnictwo Nomos, Kraków 2014. 
leksykalnych, gramatycznych (morfoskładniowych), a także narracyjnych (u ośmio- i dziesięciolatków), jednak jeden z podrozdziałów poświęciła nazywaniu. $Z$ pomocą własnego narzędzia badawczego w postaci Karty zawodów i czynności, będącego zestawem 14 zdań modelowych typu: podmiot - orzeczenie - dopełnienie, np. piekarz piecze chleb, lekarz leczy ludzi, Wątorek zgromadziła 86 nazw zawodów/wykonawców czynności ${ }^{36}$ i m.in. na tej podstawie wysnuła wniosek, że dzieci z dysfunkcją intelektualną wygenerowały $\mathrm{w}$ zestawieniu $\mathrm{z}$ dziećmi w normie intelektualnej więcej swoistych form. Zwróciła jednocześnie uwagę, na fakt, iż jedną z właściwości mowy dzieci z niepełnosprawnością intelektualną jest określanie rzeczy i pojęć za pomocą nazw o zbyt wąskim lub zbyt szerokim znaczeniu, tworzenie neologizmów w miejsce właściwych słowoform, a także stosowanie kolokwializmów ${ }^{37}$. Sformułowane przez Agnieszkę Wątorek wnioski nie budzą zdziwienia, gdyż rozbudowane w języku polskim słowotwórstwo, wyrażające się dużą różnorodnością wykładników w poszczególnych kategoriach słowotwórczych, prowadzi do trudności w ich użyciu i może skutkować tworzeniem przez dzieci nieprawidłowych form wyrazów pochodnych ${ }^{38}$.

A. Wątorek oprócz ośmio- i dziesięciolatków z diagnozą niepełnosprawności intelektualnej w stopniu lekkim przebadała też dzieci w normie klinicznej, należących do dwu grup kontrolnych - jednej dobranej ze względu na wiek inteligencji probantów z grupy kryterialnej, drugiej dobranej ze względu na ich wiek biologiczny. Dzieci zakwalifikowane do tych grup spełniały kryterium odpowiednio niskiego poziomu wykształcenia rodziców. Taka metodologia pozwoliła autorce dokonać optymalnej analizy różnic między dziećmi z lekką niepełnosprawnością intelektualną a dziećmi w normie intelektualnej. Poza tym taki układ odpowiada specyfice zjawiska nie-

36 Autorka nazwy te traktuje jako nazwy zawodów, tymczasem są to nazwy należące do słowotwórczej kategorii nazw wykonawców czynności.

37 A. Wątorek, op. cit., s. 61.

38 A. Giermakowska, op. cit., s. 359-360. 
pełnosprawności intelektualnej, ponieważ uwzględnia charakterystyczne dla niej zróżnicowanie/rozbieżności pomiędzy wiekiem biologicznym, umysłowym i społecznym.

Jak podaje $\mathrm{w}$ podsumowaniu autorka, badani z lekką niepełnosprawnością intelektualną, chcąc wydobyć z pamięci nazwy zilustrowanych na obrazkach zawodów, często wymyślali własne słowoformy (np. piekarnik, szywarka, szewiec). Innym razem tworzyli formy opisowe (np. To jest ten, co...), opuszczali w zdaniach podmiot albo posiłkowali się rzeczownikami pan/pani/mama/tata czy zaimkami on/ona. Postępując tak, w niczym nie odstawali ani od pełnosprawnych przedszkolaków, ani od równolatków, którzy choć rzadziej - korzystali z wymienionych strategii ${ }^{39}$.

Poza tym autorka monografii Kompetencja językowa uczniów z lekkq niepetnosprawnościa intelektualną sformułowała na podstawie próby nazywania zawodów/wykonawców czynności następujące wnioski:

1) uczniowie z lekką niepełnosprawnością intelektualną istotnie gorzej radzili sobie z nazywaniem zawodów niż ich pełnosprawni rówieśnicy, ale porównywalnie wobec przedszkolaków ${ }^{40}$;

2) podczas badań dzieci z dysfunkcją intelektualną, podobnie jak młodsze $\mathrm{w}$ przybliżonym wieku umysłowym, potrzebowały więcej czasu niż uczniowie szkół ogólnodostępnych na przypomnienie sobie poszczególnych słów, jednak obecność form nieprawidłowych stwierdzono we wszystkich grupach ${ }^{41}$;

3) najwięcej form nieprawidłowych stwierdzono u uczniów z dysfunkcją intelektualną i wśród przedszkolaków, najmniej wśród równolatków uczniów z dysfunkcją42;

4) uczniowie z lekką niepełnosprawnością intelektualną wygenerowali najwięcej form swoistych, ale zarówno ich młodsi koledzy, jak i rówieśnicy też uciekali się do strategii uzupeł-

\footnotetext{
${ }^{39}$ A. Wątorek, op. cit., s. 199.

40 Ibidem, s. 106.

41 Ibidem, s. 107.

42 Ibidem, s. 107.
} 
niania braków leksykalnych neologizmami. Ogólnie znajomość słownictwa związanego z działalnością zawodową człowieka wśród uczniów z lekką niepełnosprawnością intelektualną okazała się niewielka w porównaniu z rówieśnikami $(44,6 \% / 77,9 \%)^{43}$. Podobny wniosek wysnuł Z. Tarkowski ${ }^{44}$, pisząc, że sprawność językowa obu grup (tj. dzieci w normie i dzieci lekko upośledzonych umysłowo) nie różni się jakościowo, lecz występują różnice ilościowe ${ }^{45}$;

5) derywowanie nowych słów od już istniejących jako przejaw twórczości leksykalnej może rekompensować niedostatki w słowniku umysłowym, ale przy okazji odsłania luki w systemie słowno-pojęciowym, niski poziom krytycyzmu i słabe wyczucie normy językowej. Dla jednych neologizmy świadczą o kreatywności dziecka, a dla innych - o niedojrzałości jego mowy. „Być może - jak pisze Wątorek - neologizmy pojawiają się tam, gdzie kończy się czyjaś wiedza i związane z nią słownictwo, aby dać ujście potrzebie werbalizacji myśli, która bywa silniejsza niż lęk przez popełnieniem błędu językowego" 46 ;

6) wyniki badań wskazują na obecność identycznych mechanizmów oraz różnych uwarunkowań nabywania znaczeń przez dzieci z zaburzeniami rozwoju intelektualnego i bez nich. Na podstawie badań ustalono, że w przypadku obu grup repre-

43 Ibidem, s. 109.

44 Z. Tarkowski, Zaburzenia mowy dzieci upośledzonych umystowo, [w:] Logopedia pytania i odpowiedzi. Podręcznik akademicki, t. II, red. T. Gałkowski, G. Jastrzębowska, Wydawnictwo UO, Opole 2013, wyd. II, s. 203-204.

${ }^{45}$ Deskrypcja zawierająca informację o ograniczeniach ilościowych zasobu leksykalnego jest niewystarczająca, gdyż pomija jakościową charakterystykę znanego dziecku słownictwa i jakościową charakterystykę popełnianych przez nie błędów. Informacje tego typu są możliwe do uzyskania tylko na drodze analizy lingwistycznej, a przeprowadzenie takiej analizy znajduje się w kompetencjach logopedy (S. Grabias, Teoria zaburzeń mowy. Perspektywy badań, typologie zaburzeń, procedury postępowania logopedycznego, [w:] Logopedia. Teoria zaburzeń mowy, red. S. Grabias, Z.M. Kurkowski, Wydawnictwo UMCS, Lublin 2012, s. 59).

${ }^{46}$ A. Wątorek, op. cit., s. 109. 
zentacje umysłowe rozlicznych elementów rzeczywistości powstają w takim samym porządku - od obiektów najbardziej charakterystycznych i powszechnych poprzez podobne do nich fizycznie do najmniej przypominających pozycje początkowe. Jednak ze względu na specyfikę przebiegu procesów myślowych u jednostek z dysfunkcją intelektualną struktura posiadanych przez nie pojęć może być mniej złożona ${ }^{47}$.

Celem artykułu jest analiza pod kątem słowotwórczym uzyskanych od dzieci z lekką niepełnosprawnością intelektualną przez A. Wątorek w próbie nazywania nazw zawodów/wykonawców czynności i próba dokonania oceny sposobów kodowania tych nazw przez te dzieci.

$\mathrm{Na}$ podstawie danych ekscerpowanych z pracy Kompetencja jezykowa uczniów z lekka niepetnosprawnościa intelektualna nie jesteśmy w stanie dokonać opisu, a następnie oceny rozumienia (recepcji, dekodowania, interpretowania) konstrukcji słowotwórczych przez dzieci z lekką niepełnosprawnością intelektualną, ponieważ nie dysponujemy wiedzą, czy dzieci posiadły: a) umiejętność ustalenia relacji semantycznej pomiędzy wyrazem podstawowym a pochodnym poprzez wskazanie elementów składowych formacji (tzn. czy potrafią sformułować parafrazę słowotwórczą $\left.{ }^{48}\right)$, b) umiejętność eksplikowania cech semantycznych ${ }^{49}$ składających się na znaczenie

47 Ibidem, s. 65.

48 Parafraza to „wielowyrazowe wyrażenie o kształcie definicji, równoznaczne z parafrazowaną nazwą, w którym użyty jest wyraz podstawowy” (R. Grzegorczykowa, J. Puzynina Słowotwórstwo, [w:] Gramatyka współczesnego języka polskiego. Morfologia, red. R. Grzegorczykowa, R. Laskowski, H. Wróbel, PWN, Warszawa 1984, s. 316). Parafraza służy do zidentyfikowania wyrazu podstawowego i ustalenia znaczenia formantu (S. Grabias, O ekspresywności języka. Ekspresja a stowotwórstwo, Wydawnictwo Lubelskie, Lublin 1981, s. 94).

49 Eksplikowanie znaczeń wyrażeń jest to „przypisywanie im równoznacznych wyrażeń bardziej analitycznych (rozczłonkowanych formalnie)" (R. Grzegorczykowa, Wprowadzenie do semantyki językoznawczej, PWN, Warszawa 1995, s. 10). Oznacza to identyfikowanie wyrazu podstawowego i rozpoznanie znaczenia formantu w odpowiedzi na pytania pomocnicze o znaczenie poszczególnych elementów składowych formacji, bez budowania parafrazy słowotwórczej. 
strukturalne analizowanej formacji. Wysoki poziom rozumienia, tj. dekodowania konstrukcji słowotwórczych gwarantuje przyswojenie umiejętności ich tworzenia czyli kodowania. Poziom rozumienia konstrukcji słowotwórczych przewyższa poziom ich tworzenia, co jest zgodne z ogólnymi prawidłami rozwoju języka - percepcja poprzedza ekspresję 50 .

Dane $\mathrm{z}$ omawianej pracy pozwalają jednak na dokonanie ich analizy językoznawczej, słowotwórczej i tym samym na wskazanie sposobów kodowania nazw zawodów/wykonawców czynności przez dzieci z lekką niepełnosprawnością intelektualną.

I tak, biorąc pod uwagę paradygmat sposobów kodowania nazw zawodów 51 /wykonawców czynności przez dzieci z dysfunkcją intelektualną, możemy wyróżnić:

1) poprawnie utworzone nazwy zawodów/wykonawców czynności, np.: lekarz, malarz, kucharz czy piekarz;

2) konstrukcje tworzone niewłaściwymi formantami, np.: kierownica 'kierowca', kuchar 'kucharz', piekarnicz 'piekarz';

3) konstrukcje tworzone ze zmianą wyrazu podstawowego, np.: naprawiacz 'szewc', naprawnik'szewc';

4) konstrukcje tworzone nie-formantami, np.: murenarz 'murarz', sprzedyniarz 'sprzedawczyni';

5) końcówki fleksyjne w roli formantów, np.: szyja 'krawcowa', szyjąca 'krawcowa';

6) wyrazy niepodzielne słowotwórczo, np.: zegar 'zegarmistrz';

7) związki wyrazowe, np.: naprawiacz butów 'szewc', naprawiacz zegarków 'zegarmistrz', pan butowy 'szewc', pan kierownik 'kierowca', 'pan murowany 'murarz', pan naprawiak 'zegarmistrz', pan pożar 'strażak', pani spożywcza 'sprzedawczyni', strażak Sam 'strażak'.

${ }^{50}$ E. Muzyka-Furtak, Głuchota i niedostuch - mechanizmy nabywania wyrazów pochodnych, "Logopedia” 2009, nr 38, s. 163.

51 Paradygmat sposobów kodowania przyjęłam za E. Muzyką-Furtak, Konstrukcje słowotwórcze w świadomości językowej dzieci niestyszących, Wydawnictwo Uniwersytetu Marii Curie-Skłodowskiej, Lublin 2010, s. 237. 
Oceniając kompetencję słowotwórczą dzieci z niepełnosprawnością intelektualną w stopniu lekkim, należy zwrócić uwagę na fakt, czy nowo powstałe wyrazy utworzone są zgodnie $\mathrm{z}$ istniejącymi w języku polskim wzorcami słowotwórczymi, czy też od tych wzorców odbiegają. Pomocny może być tu funkcjonujący w literaturze przedmiotu podział na neologizmy systemowe (potencjalne) i pozasystemowe.

Analiza materiału pod kątem słowotwórczym pokazała, że dzieci z lekką niepełnosprawnością intelektualną tworzą zarówno neologizmy systemowe (potencjalne) (lub pozornie systemowe), jak i neologizmy pozasystemowe.

Neologizmy systemowe (potencjalne) powielają utarte schematy tworzenia słów ${ }^{52}$, opierają się o istniejące w języku modele słowotwórcze ${ }^{53}$. Są to wyrazy nowe, utworzone zgodnie z obowiązującymi regułami, ale nieustabilizowane w normie leksykalnej (nieistniejące w zasobie leksykalnym danego języka). Ich znaczenie realne jest równe znaczeniu strukturalnemu. Oznacza to, że takie derywaty są zrozumiałe bez kontekstu, w którym zostały użyte, gdyż ich znaczenie można rozszyfrować na podstawie samej znajomości języka ${ }^{54}$.

Wśród neologizmów systemowych można wyróżnić:

- neologizmy utworzone za pomocą niewłaściwych (kategorialnych) formantów słowotwórczych. Są to nowe wyrazy z formantami typowymi dla danej kategorii słowotwórczej, słowa „nienaganne pod względem strukturalnym”, ,dotychczas niespotykane, choć utworzone poprawnie" 55 ; przykłady z monografii A. Wątorek: górniarz 'górnik', malowacz 'malarz', malownik 'malarz', murownik 'murarz', piekarnik 'piekarz', skleparka

52 J. Puzynina, O pojęciu potencjalnych formacji stowotwórczych, „Poradnik Językowy" 1966, z. 8, s. 332.

53 D. Buttler, Polski dowcip językowy, PWN, Warszawa 1968; S. Grabias, Paronimia jako proces leksykalny, „Socjolingwistyka” 1982, nr 4, s. 75-88.

${ }^{54}$ H. Jadacka, Kultura języka polskiego. Fleksja, słowotwórstwo, składnia, PWN, Warszawa 2005.

55 D. Buttler, Polski dowcip językowy, PWN, Warszawa 1968, s. 152. 
'sklepowa', szywaczka 'szwaczka, krawcowa', zegarnik 'zegarmistrz';

- neologizmy utworzone od niewłaściwych podstaw słowotwórczych. Znajdują się tu derywaty utworzone od indywidualnie wybranych przez dziecko podstaw słowotwórczych (nienormatywny wybór wyrazu jako podstawy dla tworzonego derywatu), ale powstałe poprzez dodanie formantu charakterystycznego dla danej kategorii słowotwórczej. Maria Chmura-Klekotowa ${ }^{56}$ takie neologizmy nazywa pojęciowymi; przykłady: badaczka 'lekarka', budowarz 'murarz', budowlarz 'murarz', budownik 'murarz', buciarz 'szewc', butarz 'szewc', ceglarz 'murarz', chlebarz 'piekarz', ciężarownik 'kierowca', ciężarówkarz 'kierowca', dostawca 'kierowca', jeżdżacz 'kierowca', kamieniarz 'górnik', kopalniarz 'górnik', kopalnik 'górnik', podbijacz 'szewc', przewoźnik 'kierowca', ratownik 'strażak', uszycielka 'krawcowa', wiertak' górnik'.

Neologizmy pozasystemowe stanowią przeciwieństwo neologizmów potencjalnych. Określa się je także jako indywidualizmy lub okazjonalizmy ${ }^{57}$. Są to nowe wyrazy utworzone niezgodnie $\mathrm{z}$ modelami słowotwórczymi języka polskiego. Zalicza się do nich neologizmy niemotywowane przez żaden istniejący wyraz, tzw. neologizmy absolutne, formacje o nietypowych podstawach słowotwórczych lub izolowanych elementach w funkcji formantu, a także fonetyczne lub morfologiczne zniekształcenia struktury wyrazu lub dezintegracje struktur wyrazowych nieliczące się z granicami morfologicznymi ${ }^{58}$. Nazywane bywają również sytuacyjnymi ze względu na to, że stanowić mogą jednorazową, spontaniczną reakcję na dany bodziec ${ }^{59}$.

${ }_{56}$ M. Chmura-Klekotowa, Neologizmy słowotwórcze w mowie dzieci, „Prace Filologiczne" 1971, nr 21, s. 99-235.

${ }^{57}$ K. Chruścińska, O formacjach potencjalnych i okazjonalizmach, [w:] Z zagadnień stownictwa wspótczesnego jezzyka polskiego, red. M. Szymczak, Wydawnictwo ZNiO, Wrocław 1978, s. 69-79; S. Grabias, op. cit.

58 Ibidem.

${ }^{59}$ D. Buttler, Neologizm i terminy pokrewne, „Poradnik Językowy” 1962, z. 5-6, s. $235-244$. 
Wśród pozasystemowych formacji słowotwórczych tworzonych przez dzieci z lekką niepełnosprawnością intelektualną można wyróżnić następujące:

- neologizmy utworzone za pomocą niewłaściwych (niekategorialnych) formantów. Są to derywaty tworzone przypadkowymi formantami (nietypowymi dla danej kategorii słowotwórczej), przez co ich znaczenie jest niezrozumiałe; przykłady: sprzedawczynia 'sprzedawczyni', szywalnia 'szwaczka';

- neologizmy utworzone od niewłaściwych podstaw słowotwórczych. Są to formacje powstałe poprzez dodanie do nienormatywnie wybranej podstawy słowotwórczej formantu nietypowego dla danej kategorii; przykłady: stukowiec 'szewc';

- neologizmy utworzone od nietypowych podstaw słowotwórczych. Należą do nich „wyrazy pochodne od podstaw, które normalnie nie tworzą derywatów określonego rodzaju (...) lub w ogóle nie bywają słowotwórczo rozwijane"60. Tworzą je dzieci o bardzo niskim poziomie sprawności słowotwórczej; przykłady jw.: prawienek 'zegarmistrz', prowiciel 'kierowca'.

Dokonując oceny kompetencji słowotwórczej dzieci z niepełnosprawnością intelektualną na podstawie materiału ekscerpowanego z monografii A. Wątorek, można wysnuć dodatkowo następujące wnioski:

1) dzieci z retardacją wykorzystują zasadę przejrzystości znaczenia, tj. często w neologizmach używają formantów, które znają;

2) wybierają formanty najbardziej produktywne $\mathrm{w}$ kategorii nazw zawodów/wykonawców czynności, tj. -arz, -nik, -acz;

3) przy pomocy formantu -arz utworzyły 24 formy (na 86 zgromadzonych), por. np.: budowarz 'murarz', górniarz 'górnik', kopalniarz 'górnik', pan zegarz 'zegarmistrz'. Formant ten posłużył im nawet do tworzenia form sklepiarz, sprzedyniarz nazywających żeńskich wykonawców czynności, tj. 'sklepową,

${ }^{60}$ D. Buttler, Polski dowcip językowy, PWN, Warszawa 1968, s. 183. 
sprzedawczynię'. Z formantem -nik odnotowałam 18 form, por. np.: ciężarownik 'kierowca', malownik 'malarz', naprawnik 'zegarmistrz', zegarnik 'zegarmistrz'. Formant -arz posłużył dzieciom do utworzenia 6 form, por. np.: jeżdzacz 'kierowca', malowacz 'malarz', naprawiacz zegarków 'zegarmistrz', podbijacz 'szewc', szywacz butów 'szewc';

4) zdarzało się, że dzieci nie znając nazw zawodów:

a) wyławiały z sieci semantycznej leksemy kategorii nadrzędnej, por. np.: naprawiacz 'szewc', naprawiak 'zegarmistrz', naprawiarz 'szewc', naprawnik 'szewc', 'zegarmistrz', pracownik 'murarz', robotnik 'górnik' lub podrzędnej, por. np.: chlebarz 'piekarz', 'ciężarownik 'kierowca', ciężarówkarz 'kierowca'. Tego typu realizacje - jak pisze Alicja Giermakowska - mogą oznaczać, że dziecko nie ma właściwego obrazu relacji wynikających z posiadania cech przez obiekty znajdujące się na różnych poziomach hierarchii semantycznej ${ }^{61}$;

b) przytaczały zupełnie inne, często nawet niekojarzące się z właściwymi, nazwy zawodów/wykonawców czynności, por. np.: murenarz 'górnik', rolnik 'górnik'.

Co prawda nie posiadamy danych na temat umiejętności eksplikacji cech semantycznych $\mathrm{u}$ dzieci z lekką niepełnosprawnością intelektualną, jednak możemy przypuszczać, że kilka nazw utworzyły one na zasadzie asocjacji, por. kominiarz 'górnik' (być może dlatego, że obaj noszą ciemny strój i są podobnie ubrudzeni na twarzy), kowal 'szewc' (być może dlatego, że ma szewskie kowadło), krawiec 'szewc' (bo obaj szyją, jeden ubrania, drugi buty), prowiciel 'kierowca' (może od prowadzić), stukowiec 'szewc' (być może dlatego, że stuka w obcasy przy zmianie fleków), złotnik 'górnik' (być może dlatego, że węgiel nazywany jest czarnym złotem).

Poza tym być może jakieś fonetyczne (brzmieniowe) skojarzenia przyczyniły się do powstania formacji mtynarz 'murarz'.

61 A. Giermakowska, op. cit., s. 364. 


\section{Podsumowanie}

Dokonanie opisu rozumienia (recepcji, dekodowania, interpretowania) i tworzenia (ekspresji, kodowania) konstrukcji słowotwórczych przez dzieci z lekką niepełnosprawnością intelektualną określenie sposobu istnienia konstrukcji słowotwórczych w świadomości językowej dzieci z retardacją jest o tyle ważne, że brak jest badań, a w związku z tym i opracowań dotyczących kompetencji słowotwórczych tych dzieci.

Wyniki badań pozwolą m.in. odpowiedzieć na pytania nurtujące wielu pedagogów, a mianowicie, czy dzieci z dysfunkcją intelektualną (mowa oczywiście o lekkiej niepełnosprawności intelektualnej) są $w$ stanie realizować tę samą dla wszystkich podstawę programową, czerpać wiedzę z podręczników znajdujących się $\mathrm{w}$ powszechnym obiegu, przystępować do sprawdzianów oraz egzaminów kompetencyjnych na ujednoliconych zasadach ${ }^{62}$.

\section{Bibliografia}

Baudouin de Courtenay J., Spostrzeżenia nad jezzykiem dziecka, wybr. i oprac. M. Chmura-Klekotowa, Wydawnictwo Ossolineum, Wrocław 1974.

Błeszyńska L., Zasób słownictwa uczniów z niepetnosprawnościa intelektualna w stopniu lekkim klas gimnazjalnych - diagnoza i propozycje rozwiązań, [w:] Nauczanie uczniów $z$ niepetnosprawnościa intelektualna $w$ stopniu lekkim. Wybrane problemy $z$ teorii i praktyki, red. S. Sadowska, Wydawnictwo Edukacyjne Akapit, Torun 2006.

Błeszyński J., Niepetnosprawność intelektualna. Mowa - język - komunikacja. Czy iloraz inteligencji wyjaśnia wszystko?, Harmonia, Gdańsk 2013.

Buttler D., Neologizm i terminy pokrewne, „Poradnik Językowy” 1962, z. 5-6.

Buttler D., Polski dowcip jezzykowy, PWN, Warszawa 1968.

Chmura-Klekotowa M., Neologizmy stowotwórcze w mowie dzieci (I), „Poradnik Językowy" 1967, nr 10.

Chmura-Klekotowa M., Neologizmy słowotwórcze w mowie dzieci, „Poradnik Językowy" 1968, nr 1.

Chmura-Klekotowa M., Neologizmy słowotwórcze w mowie dzieci, „Prace Filologiczne” 1971 , nr 21.

62 Por. A. Wątorek, op. cit., s. 12. 
Chruścińska K., O formacjach potencjalnych i okazjonalizmach, [w:] Z zagadnień słownictwa wspótczesnego jezzyka polskiego, red. M. Szymczak, Wydawnictwo ZNiO, Wrocław 1978.

Dawid Ł., Neologizmy przykładem kreatywności językowej uczniów klas młodszych, [w:] Problemy edukacji lingwistycznej, pod red. M.T. Michalewskiej, Oficyna Wydawnicza „Impuls”, Katowice 1999.

Dziurda-Multan A., Dziecięce sposoby tworzenia nazw, Wydawnictwo KUL, Lublin 2008.

Gąsiorek K., Rozumienie przez dzieci i młodzież szkolna rzeczowników abstrakcyjnych z uwzględnieniem czynników wiekowych i środowiskowych, [w:] Zagadnienia komunikacji językowej dzieci i młodzieży, red. J. Porayski-Pomsta, Dom Wydawniczy „Elipsa”, Warszawa 1991.

Giermakowska A., Ocena kompetencji stowotwórczej uczniów z trudnościami w czytaniu i pisaniu na poziomie edukacji wczesnoszkolnej, „,Szkoła Specjalna” 2012, nr 5.

Grabias S., O ekspresywności języka. Ekspresja a stowotwórstwo, Wydawnictwo Lubelskie, Lublin 1981.

Grabias S., Paronimia jako proces leksykalny, „Socjolingwistyka” 1982, nr 4.

Haman E., Early productivity in derivation. A case study of diminutives in the acquisition of Polish, „Psychology of Language and Communication” 2003, nr 7(1).

Haman E., Stowotwórstwo dziecięce w badaniach psycholingwistycznych, Wydawnictwo Lexem, Warszawa 2013.

Haman E., Status wyrazów pochodnych w stowniku dziecka - analiza psycholingwistyczna (niepublikowana rozprawa doktorska napisana pod kierunkiem prof. dr hab. Barbary Bokus, Wydział Psychologii UW) 2000; Haman E., Semantic vs. formal determinants of derivational morphology development: The case of derived nouns in Polish, „Polish Psychological Bulletin” 2000, nr 31(2).

Jadacka H., Kultura języka polskiego. Fleksja, słowotwórstwo, składnia, PWN, Warszawa 2005.

Jęczeń U., Językowa projekcja emocji na przykładzie wypowiedzi dzieci upośledzonych umystowo $i$ dzieci w normie intelektualnej (niepublikowana rozprawa doktorska), Lublin 2005.

Jęczeń U., Językowa projekcja emocji. Emocje w zachowaniach językowych dzieci upośledzonych umystowo i dzieci w normie intelektualnej, [w:] Jezyk - interakcja - zaburzenia mowy. Metodologia badań, red. T. Woźniak, A. Domagała, Wydawnictwo UMCS, Lublin 2007.

Kaczmarek L., Nasze dziecko uczy się mowy, Wydawnictwo Lubelskie, Lublin 1966.

Kaczorowska-Bray K., Wyrażenia przyimkowe w mowie dzieci upośledzonych umysłowo w stopniu umiarkowanym i lekkim (niepublikowana rozprawa doktorska), Gdańsk 2007.

Krakowiak K., Fonogesty jako narzędzie formowania języka u dzieci z uszkodzonym stuchem, seria: Komunikacja językowa i jej zaburzenia, t. 9, red. S. Grabias, Wydawnictwo Uniwersytetu Marii Curie-Skłodowskiej, Lublin 1995. 
Krzemińska D., Język i dyskurs codzienny osób z niepetnosprawnościa intelektualna, Oficyna Wydawnicza „Impuls”, Kraków 2012.

Michalik M., Diagnozowanie kompetencji lingwistycznej ucznia szkoty specjalnej, Wydawnictwo Naukowe Akademii Pedagogicznej, Kraków 2006.

Michalik M., Kompetencja składniowa w normie $i$ w zaburzeniach, Wydawnictwo Naukowe Uniwersytetu Pedagogicznego, Kraków 2011.

Minczakiewicz E., Kształtowanie i usprawnianie mowy dzieci upośledzonych umysłowo w stopniu umiarkowanym i znacznym, „Szkoła Specjalna” 1984, nr 3.

Minczakiewicz E., Rozwój języka mówionego uczniów młodszych klas szkoły specjalnej dla lekko upośledzonych umystowo w toku zamierzonych oddziatywań stymulacyjnych, „Logopedia” 1994, nr 21.

Minczakiewicz E., Z badań nad zaburzeniami mowy u dzieci upośledzonych umysłowo, [w:] Z zagadnień oligofrenopedagogiki, t. 2, red. J. Pańczyk, Wydawnictwo WSPS, Warszawa 1989.

Minczakiewicz E., Zaburzenia mowy i ich odbicie w piśmie uczniów młodszych klas szkoły specjalnej dla lekko upośledzonych umystowo, „Logopedia” 1993, nr 20.

Minczakiewicz E., Zaburzenia mowy u osób z upośledzeniem umystowym, „Scholasticus” 1993, nr 1.

Mnich M., Sprawność językowa dzieci w wieku wczesnoszkolnym, Oficyna Wydawnicza „Impuls”, Kraków 2002.

Muzyka E., Acquisition of word-formation categories by children with hearing loss, "Psychology of Language and Communication" 2008, nr 12(2).

Muzyka E., Sposoby interpretowania konstrukcji słowotwórczych przez dzieci niestyszące, „Logopedia” 2007, nr 36.

Muzyka-Furtak E., Głuchota i niedostuch - mechanizmy nabywania wyrazów pochodnych, „Logopedia” 2009, nr 38.

Muzyka-Furtak E., Jakościowa charakterystyka zaburzeń leksykalnych dzieci z uszkodzonym stuchem, „Logopedia” 2013, nr 42.

Muzyka-Furtak E., Konstrukcje stowotwórcze a kategorie poznawcze dzieci niestyszacych, [w:] Jezyk a kultura, t. 22, Idiolekty w różnych sferach komunikacji, red. A. Żurek, Wydawnictwo Uniwersytetu Wrocławskiego, Wrocław 2011.

Muzyka-Furtak E., Konstrukcje słowotwórcze w świadomości językowej dzieci niestyszacych, Wydawnictwo Uniwersytetu Marii Curie-Skłodowskiej, Lublin 2010.

Muzyka-Furtak E., Kwestionariusz słowotwórczy w ocenie kompetencji językowej dzieci z zaburzeniem stuchu, [w:] Metody i narzędzia diagnostyczne w logopedii, red. M. Kurowska, E. Wolańska, Wydawnictwo Dom Wydawniczy Elipsa, Warszawa 2015.

Nadolska H., Poziom inteligencji a sprawność narracji. (Z badań nad mowa narracyjna dzieci upośledzonych umysłowo w stopniu lekkim $i$ petnosprawnych umystowo), „Roczniki Pedagogiki Specjalnej” 1994, nr 5.

Nadolska H., Kompetencja narracyjna uczniów o różnym poziomie intelektualnym. Przejawy, uwarunkowania, tendencje rozwojowe, Wydawnictwo Erbe, Białystok 1995. 
Nadolska H., Poziom inteligencji a sprawność relacjonowania zdarzeń. Wybrane aspekty badań nad kompetencja narracyjna dzieci petnosprawnych $i$ upośledzonych umystowo w stopniu lekkim, „Kultura i Edukacja” 1993, nr 4.

Pastuchowa M., O stowotwórstwie z perspektywy leksykalnej, [w:] Sztuka czy rzemiosto? Nauczyć Polski i polskiego, red. A. Achtelik, J. Tambor, wyd. Gnome, Katowice 2007.

Przybysz-Piwkowa M., Wyodrębnianie znaczeń form językowych w neologizmach dziecięcych, [w:] Jezzykowy obraz świata dzieci i młodzieży, red. J. Ożdżyński, Wydawnictwo Wyższej Szkoły Pedagogicznej, Kraków 1995.

Puzynina J., O pojęciu potencjalnych formacji stowotwórczych, „Poradnik Językowy” 1966, z. 8.

Rakowska A., Jezyk - komunikacja - niepetnosprawność. Wybrane zagadnienia, Wydawnictwo Naukowe Akademii Pedagogicznej, Kraków 2003.

Rakowska A., Rozwój systemu gramatycznego u dzieci głuchych, Wydawnictwo Naukowe Wyższej Szkoły Pedagogicznej, Kraków 1992.

Sadowska S., Uсzeń z niepetnosprawnościa intelektualna w stopniu lekkim w szkolnej sytuacji komunikacyjnej. O realizacji zadań wspomagania rozwoju umiejętności mówienia i pisania, [w:] Nauczanie uczniów z niepetnosprawnościa intelektualną w stopniu lekkim. Wybrane problemy z teorii i praktyki, red. S. Sadowska, Wydawnictwo Edukacyjne Akapit, Toruń 2006.

Sprawności językowe dzieci upośledzonych umystowo w stopniu lekkim, red. J. Bałachowicz, J. Paluszewski, Wydawnictwo WSPS, Warszawa 1995.

Synowiec H., Rozwój stownictwa nazywającego rozwój osobowości w języku dzieci i młodzieży, Wydawnictwo Uniwersytetu Śląskiego, Katowice 1985.

Synowiec H., Z badań nad stownictwem dzieci przedszkolnych, [w:] Z teorii i praktyki dydaktycznej jezzyka polskiego, t. 3, red. J. Kram, E. Polański, Wydawnictwo Uniwersytetu Śląskiego, Katowice 1980.

Szuman S., Rozwój treści stownika dzieci. Zagadnienia i niektóre wyniki badań, [w:] O rozwoju jezzyka i myślenia dziecka, red. S. Szuman, Wydawnictwo PWN, Warszawa 1968.

Szuniewicz A. Próba badania wad mowy dzieci upośledzonych umystowo w warszawskich szkołach specjalnych, „Logopedia” 1967, nr 7.

Tarkowski Z., Agramatyzm u uczniów lekko upośledzonych umystowo, [w:] Rewalidacja dzieci ze ztożonymi upośledzeniami, red. Z. Sękowska, Wydawnictwo UMCS, Lublin 1988.

Tarkowski Z., Zaburzenia mowy dzieci upośledzonych umystowo, [w:] Logopedia - pytania i odpowiedzi. Podręcznik akademicki, t. II, red. T. Gałkowski, G. Jastrzębowska, Wydawnictwo UO, Opole 2013, wyd. II.

Wątorek A. Kompetencja językowa uczniów z lekka niepetnosprawnościa intelektualna, Wydawnictwo Nomos, Kraków 2014.

Zarębina M., Kształtowanie się systemu językowego dziecka, Wydawnictwo Ossolineum, Wrocław 1965.

Zarębina M., Język polski w rozwoju jednostki. Analiza tekstów dzieci do wieku szkolnego. Rozwój semantyczny języka dziecka, Wydawnictwo Naukowe Wyższej Szkoły Pedagogicznej, Kraków 1980. 